\title{
SCIENTIFIC PHYSICAL TRAINING ON THE CLINICAL RECOVERY OF CHRONIC FATIGUE INJURY
}

\author{
TREINO FÍSICO CIENTÍFICO PARA A RECUPERAÇÃO DE LESÕES POR FADIGA CRÔNICA
}

ENTRENAMIENTO FÍSICO CIENTÍFICO PARA LA RECUPERACIÓN DE LESIONES POR FATIGA CRÓNICA

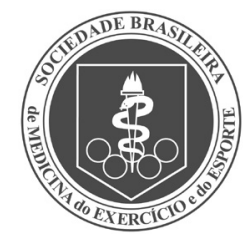

Original Article

ARTIGO ORIGINAL

Artículo Original
Haibo Xu' (ID

(Physical Education Professional)

1. Institute of Physical Education and Sports, Jining Normal

University, Ulanqab, China.

Correspondence

Haibo Xu

Ulanqab, China, 012000.

xuxurusheng1984@163.com

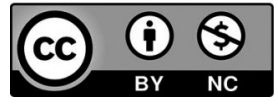

\begin{abstract}
Introduction: Chronic fatigue syndrome is also called chronic fatigue and immune dysfunction syndrome. This disease has now become a common disease in modern medicine. Objective: To explore and analyze the effect of exercise therapy on chronic fatigue syndrome. Methods: We selected 70 patients with chronic fatigue syndrome for the experiment. The exercise group performed gradual exercise, and the control group was inactive. Results: Appropriate and regular exercise can achieve ideal results in the treatment of chronic fatigue syndrome. Conclusion: Studying methods to prevent and recover from fatigue syndrome will help in understanding and focusing attention on the topic of fatigue, as well as being aware of the methods of self-prevention of fatigue syndrome. Level of evidence Il; Therapeutic studies - investigation of treatment results.
\end{abstract}

Keywords: Sports; Fatigue syndrome, chronic; Athletic injuries.

\section{RESUMO}

Introdução: A síndrome de fadiga crônica é também chamada de fadiga crônica e síndrome de disfunção imune. Esta doença tem se tornado comum na medicina moderna. Objetivo: Explorar e analisar o efeito da terapia por exercicio na síndrome de fadiga crônica. Métodos: Selecionamos 70 pacientes com síndrome de fadiga crônica para o experimento. O grupo de exercício praticou exercícios moderados e o grupo de controle permaneceu inativo. Resultados: Exercícios adequados e regulares podem atingir resultados ideais no tratamento da síndrome de fadiga crônica. Conclusão: O estudo de métodos para prevenir e se recuperar da síndrome de fadiga crônica ajuda ao entender e ficar atento ao tema da fadiga, assim como reconhecer os métodos de autoprevenção da síndrome da fadiga. Nível de evidência ll; Estudos terapêuticos - investigação de resultados de tratamento.

Descritores: Esportes; Sindrome de fadiga crônica; Traumatismos em atletas.

\section{RESUMEN}

Introducción: El síndrome de fatiga crónica se llama también fatiga crónica y síndrome de disfunción inmune. Esta enfermedad se ha vuelto común en la medicina moderna. Objetivo: Explorar y analizar el efecto de la terapia por ejercicio en el síndrome de fatiga crónica. Métodos: Seleccionamos 70 pacientes con síndrome de fatiga crónica para el experimento. El grupo de ejercicios practicó ejercicios moderados y el grupo de control permaneció inactivo. Resultados: Ejercicios adecuados y regulares pueden atingir resultados ideales en el tratamiento del síndrome de fatiga crónica. Conclusión: El estudio de métodos para preveniry recuperarse del síndrome de fatiga crónica ayuda a entender y estar atento al tema de la fatiga, así como reconocer los métodos de autoprevención del síndrome de fatiga. Nivel de evidencia ll; Estudios terapéuticos - investigación de resultados de tratamiento.

\section{Descriptores: Deportes; Síndrome de fatiga crónica; Traumatismos en atletas.}

\section{INTRODUCTION}

Chronic fatigue syndrome (CFS) is also called chronic fatigue and immune dysfunction syndrome. This disease has now become a common disease in modern medicine. CFS is a severe sub-health state. It is a group of symptoms characterized by long-term continuous fatigue and non-specific symptoms such as inattention, memory loss, low fever, headache, sore throat, muscle and joint pain, sleep disturbance, and depression. Long-term work and study pressure, mental stress, lack of sleep, lack of exercise, introversion, and disharmony in interpersonal relationships are all causes of CFS. The current international diagnosis of CFS is based on the standard revised by the US Centers for Disease Control in 1994 (CDC-1994). This standard mainly includes continuous or recurring severe fatigue for 6 months or more and non-workout. And can not be relieved after rest. At least 4 of the following 8 symptoms are met: (1) Short-term memory decline or difficulty concentrating. (2) Sore throat. (3) Swollen lymph nodes in the neck or axilla. (4) Myalgia. (5) Multiple joint pain. (6) Headache. (7) Sleeping body. Being in a critical period of growth and development, while facing the pressure of entering a higher school and the long-term and tense pace of study and life, the student group is straightforward to become a CFS group. CFS can cause adolescents' memory loss, decline in academic performance and severely affect their physical development and physical health. In addition, studies have shown that if CFS can be diagnosed and treated on time, it is more likely to recover. ${ }^{1}$ However, the longer the duration, the more difficult it is to cure, which can cause immeasurable harm to the patient's physical and mental health. This ultimately leads to the 
occurrence of organic diseases. CFS can also cause sudden death of the body after heavy exercise. It can be seen that the harm of CFS to young people cannot be ignored. Monitoring and prevention of adolescent CFS groups are currently one of adolescent health management and promotion tasks. Young CFS is different from adults. They have their characteristics. According to the complexity of its symptoms, many variations must be considered in the diagnosis. Studies have found that fatigue, headaches, sleep disturbances, emotional problems, sound sensitivity, and cognitive difficulties are common symptoms of CFS in adolescents.

Chronic fatigue syndrome (CFS) is also called chronic fatigue and immune dysfunction syndrome. This disease has now become a common disease in modern medicine. Related experts have also proposed to improve the symptoms of chronic fatigue syndrome through exercise, but then there has also been a phenomenon of exercise resistance. ${ }^{2}$ CFS patients can show a decrease in exercise capacity and peak oxygen intake compared with ordinary people. The heart rate will increase during sub-maximal exercise, and subjective fatigue will increase. Experts in the United States and the United Kingdom agree that gradual exercise therapy can improve the symptoms of chronic fatigue syndrome. Based on this, we designed a set of step-by-step exercise therapy to study its effect on patients with chronic fatigue syndrome.

\section{METHOD}

\section{Research object}

We selected 70 patients with chronic fatigue syndrome diagnosed and treated in a provincial People's Hospital. ${ }^{3}$ They all volunteered to participate in this experiment. We randomly divide them into two groups. There are 35 people in each group (Table 1).

Diagnostic standards content includes the following two aspects: 1. Continuous or severe recurring fatigue of unknown cause. His medical history is not less than 6 months. The current patient's professional ability, ability to receive education, personal life, and social activity ability are significantly lower than before the illness. The patient cannot be relieved after rest.

2. Have at least four items out of the 8 items not listed at the same time: (1) memory or concentration decline; (2) sore throat; (3) neck stiffness or axillary lymphadenopathy; (4) muscle pain; (5) Multiple arthralgias; (6) Repeated headaches; (7) Poor sleep quality and not relaxing after waking up; (8) Myalgias after exertion.

\section{Research methods}

\section{Physical examination}

Perform physical examinations on all research subjects to understand their basic situation and avoid dangerous situations. ${ }^{4}$ This includes blood pressure, heart rate, respiration, electrocardiogram, and lung function, as well as questionnaires to screen out people with a history of sports injuries.

\section{Questionnaire survey on quality of life and physical symptoms}

1. The fatigue rating scale survey includes 14 items. Among them, eight items reflect physical fatigue, and six items reflect mental fatigue.

Table 1. Basic information of the subjects.

\begin{tabular}{c|c|c|c}
\hline & Test group & Control group & Total \\
\hline Male/n & 10 & 12 & 2 \\
\hline Height/cm & $170.7 \pm 4.20$ & $172.43 \pm 2.74$ & \\
\hline Weight/kg & $69.77 \pm 5.1$ & $72.25 \pm 7.21$ & \\
\hline Female/n & 25 & 23 & 48 \\
\hline Height/cm & $159.15 \pm 1.23$ & $160.23 \pm 3.47$ & \\
\hline Weight/kg & $58.14 \pm 3.11$ & $55.12 \pm 4.27$ & \\
\hline Total & 35 & 35 & 70 \\
\hline Average age & $20.44 \pm 5.17$ & & \\
\hline
\end{tabular}

2. Comprehensive investigation of CFS status: 1) Improved Cornell Medical Index (CMI). We use the respiratory system, cardiovascular system, digestive system, skeletal muscle, and nervous system. Investigate the physical symptoms of the research subjects. 2) The questionnaire for a comprehensive assessment of the quality of life selects one dimension of social function. We evaluate the main social fields (education, occupation, economic life) and community social life of the research objects.

\section{Experimental method}

We randomly divided 70 subjects into two groups with 35 people in each group. The experimental group received gradual exercise therapy for half a year. The control group paid attention to rest according to the doctor's advice. Relax, but do not engage in particular physical exercise. ${ }^{5}$ The duration of the initial phase of exercise is 5 to 15 minutes. Exercise takes the midpoint of the heart rate reached during the submaximal exercise test as the average heart rate. Exercise intensity is based on this heart rate value.

The gradual exercise composed of aerobic capacity mainly uses the body's large muscle groups to exercise. Participants exercise under guidance every two days, taking into account the possibility of exercise resistance in chronic fatigue syndrome. If the patient has repeated illness or worsening symptoms, the time for the next exercise will be shortened or stopped accordingly. ${ }^{6}$ The subsequent exercise time is also reduced to the extent that the patient feels fit. Review their progress with each patient every four weeks to determine the exercise therapy plan for the next month. The patients and their family members recorded their sleep time before and after treatment.

\section{Statistical processing}

We used SPSS software to process all the data, and the results were expressed as mean \pm standard deviation. Paired t-test was used for pre-and post-control, and an independent-sample t-test was used for inter-group control. We use $\mathrm{P}<0.05$ as the significance level. Under the condition of continuity and boundedness, we combine the wavelet kernel space matching method to match the associated features of sports wrong actions. ${ }^{7}$ Calculate the value of the sports machine vision information collection template in the boundary layer of the physical sub-region. Fix the ray direction in the template. We respectively obtain the coordinates of the intersection point of the feature movement frame of the wrong action image in sports. The Euler-Lagrange equation describes the three-dimensional data field of the wrong action in sports as:

$$
\begin{aligned}
& \frac{\partial \varphi}{\partial t}=-\delta(\varphi)\left[\theta\left(\lambda_{1} e_{1}^{L B F}-\lambda_{2} e_{2}^{L B F}\right)+(1-\theta)\left(\lambda_{1} e_{1}^{L G F}-\lambda_{2} e_{2}^{L G F}\right)\right]+ \\
& v \delta(\varphi) \operatorname{div}\left(\frac{\nabla \varphi}{|\nabla \varphi|}\right)+\mu\left(\nabla^{2} \varphi-\operatorname{div}\left(\frac{\nabla \varphi}{|\nabla \varphi|}\right)\right)
\end{aligned}
$$

The calculation formula of $e_{1}^{L B F}, e_{2}^{L B F}, e_{1}^{L G F}, e_{2}^{L G F}$ is:

$\left\{\begin{array}{l}e_{1}^{L B F}=\int_{\Omega} K_{\sigma}(y-x)\left|I(x)-f_{1}(y)\right|^{2} d y \\ e_{2}^{L B F}=\int_{\Omega} K_{\sigma}(y-x)\left|I(x)-f_{2}(y)\right|^{2} d y\end{array}\right.$

$\left\{\begin{array}{l}e_{1}^{L G F}=\int_{\Omega} K_{\sigma}(y-x)\left|I^{G}(x)-f_{1}^{G}(y)\right|^{2} d y \\ e_{2}^{L G F}=\int_{\Omega} K_{\sigma}(y-x)\left|I^{G}(x)-f_{2}^{G}(y)\right|^{2} d y\end{array}\right.$

We use the local binary fitting method for sports machine vision information collection and motion vector library reconstruction. ${ }^{8}$ The regional pixel information of sports images under computer vision is:

$L=J(w, e)-\sum_{i=1}^{N} a_{i}\left\{w^{T} \varphi\left(x_{i}\right)+b+e_{i}-y_{i}\right\}$ 
$a_{i}$ represents the configuration sequence of the standard action. $J$ $(w, e)$ is the repeated pixel point of the sports position under machine vision. $\varphi\left(x_{i}\right)$ is the contour feature distribution function in the standard motion vector library.

\section{RESULTS}

\section{Sleep time before and after treatment in the two groups}

The results showed that the sleep time of the experimental group was significantly prolonged after treatment (Table 2).

\section{Fatigue scale scores before and after treatment and qua- lity of life comprehensive assessment questionnaire score results for the two groups}

The work-study factor scores of the experimental group increased significantly after treatment $(p<0.05)$. There were no statistically significant changes in amateur entertainment factor scores, marriage and family factor scores, social support factor scores, and interpersonal communication factors, respectively (Table 3 and 4)

\section{The somatic symptom score results of the two groups of patients before and after the experiment}

Cornell Medical Index (CMI) scoring results showed that the experimental group was treated with eye and ear scores (A), musculoskeletal system scores (E), nervous system scores (F), fatigue scores (G) Significantly better than before treatment $(P<0.05)$. However, there was no significant change in the points of the respiratory system (B), cardiovascular points (C), and digestive system (D). There was no significant change in all indicators of the control group.

Table 2. Sleep time before and after treatment in the two groups.

\begin{tabular}{c|c|c}
\hline \multirow{2}{*}{ Test group } & & Sleep time/h \\
\hline \multirow{2}{*}{ Control group } & Before the experiment & $6.74 \pm 1.25$ \\
\cline { 2 - 3 } & After the experiment & $7.38 \pm 2.16$ \\
\cline { 2 - 3 } & Before the experiment & $6.82 \pm 2.10$ \\
\hline \multirow{2}{*}{ After the experiment } & $6.89 \pm 1.78$ \\
\hline
\end{tabular}

Table 3. Comparison of fatigue scale scores before and after the two groups.

\begin{tabular}{c|c|c|c|c}
\hline \multirow{2}{*}{ Test group } & $\begin{array}{c}\text { Fatigue } \\
\text { total score }\end{array}$ & $\begin{array}{c}\text { Physical } \\
\text { fatigue }\end{array}$ & $\begin{array}{c}\text { Mental } \\
\text { fatigue }\end{array}$ \\
\cline { 2 - 5 } & Before the experiment & $10.77 \pm 3.80$ & $4.34 \pm 2.31$ & $4.11 \pm 1.23$ \\
\cline { 2 - 5 } Control & After the experiment & $7.65 \pm 1.89$ & $2.79 \pm 1.78$ & $3.22 \pm 1.46$ \\
\cline { 2 - 5 } group & Before the experiment & $10.24 \pm 2.47$ & $4.36 \pm 1.52$ & $4.35 \pm 2.19$ \\
\cline { 2 - 5 } & After the experiment & $9.98 \pm 3.55$ & $4.01 \pm 1.64$ & $3.87 \pm 1.72$ \\
\hline
\end{tabular}

Table 4. Comparison of the total assessment questionnaire scores for the quality of life between the two groups before and after treatment.

\begin{tabular}{c|c|c|c|c|c|c}
\hline & & $\begin{array}{c}\text { Interpersonal } \\
\text { communication }\end{array}$ & $\begin{array}{c}\text { Work and } \\
\text { study }\end{array}$ & $\begin{array}{c}\text { social } \\
\text { support }\end{array}$ & $\begin{array}{c}\text { Amateur } \\
\text { entertainment }\end{array}$ & $\begin{array}{c}\text { married } \\
\text { family }\end{array}$ \\
\hline $\begin{array}{c}\text { Test } \\
\text { group }\end{array}$ & $\begin{array}{c}\text { Before the } \\
\text { experiment }\end{array}$ & $9.93 \pm 2.14$ & $11.46 \pm 3.72$ & $4.87 \pm 1.43$ & $11.30 \pm 2.46$ & $13.28 \pm 2.76$ \\
\hline & $\begin{array}{c}\text { After the } \\
\text { experiment }\end{array}$ & $10.10 \pm 1.87$ & $13.74 \pm 4.25$ & $5.0 \pm 2.37$ & $11.49 \pm 3.18$ & $13.26 \pm 3.12$ \\
\hline $\begin{array}{c}\text { Control } \\
\text { group }\end{array}$ & $\begin{array}{c}\text { Before the } \\
\text { experiment }\end{array}$ & $10.21 \pm 1.92$ & $11.23 \pm 1.65$ & $5.1 \pm 1.09$ & $12.30 \pm 1.38$ & $13.42 \pm 1.82$ \\
\hline & $\begin{array}{c}\text { After the } \\
\text { experiment }\end{array}$ & $10.10 \pm 3.01$ & $11.73 \pm 2.4$ & $5.23 \pm 1.3$ & $11.98 \pm 2.20$ & $13.51 \pm 2.70$ \\
\hline
\end{tabular}

\section{DISCUSSION}

The pathogenesis of CFS is more complicated. Most people believe that chronic fatigue syndrome may result from a neuroendocrine-immune network disorder caused by multiple factors such as viral infection and stress. As the cause and pathology of CFS are not very clear at present, an effective treatment method has not been found clinically. ${ }^{9}$ However, the currently used treatment methods such as antiviral, immune enhancement, hormone supplementation, and anti-depression have not obtained apparent effects. This is a mainly symptomatic treatment to relieve symptoms. Sports medicine experts recognize that exercise can improve the symptoms of chronic fatigue syndrome.

The experimental results show that the step-by-step exercise method can effectively improve the sleep of patients. The possible mechanism is that the 24-hour circadian rhythm adjustment ability of CFS patients is lacking. The internal circadian rhythm does not match the 24-hour natural rhythm, making the body clock rhythm prolonged. Increased sleep time and decreased sleep quality have caused daytime fatigue, insomnia at night, and cognitive dysfunction. Vigorous unplanned exercise may further disrupt the biological rhythm. The gradual exercise therapy can enhance the body's ability to regulate circadian rhythms.

\section{CONCLUSION}

The form of exercise we choose to walk is also a daily exercise. This will not cause the human body to produce an initial stress response. And gradual exercise can also improve the sleep phase so that patients can improve sleep efficiency and fully recover their physical strength. In addition, research data shows that the blood circulation of people who exercise moderately is 2 times higher than that of ordinary people. This can provide sufficient oxygen and nutrients to the brain tissue. This can make the brain work more freely and think more quickly.

The author declare no potential conflict of interest related to this article

\section{REFERENCES}

1. Hodges $L$, Nielsen $T$, Cochrane D, Baken D. The physiological time line of post-exertional malaise in myalgic encephalomyelitis/chronic fatigue syndrome (ME/CFS). Translational Sports Medicine. 2020;3(3);243-9. doi: 10.3390/ijerph18052366

2. Nelson MJ, Buckley JD, Thomson RL, Clark D, Kwiatek R, Davison K. Diagnostic sensitivity of 2-day cardiopulmonary exercise testing in myalgic encephalomyelitis/chronic fatigue syndrome. JTransl Med. 2019;17(1):80. doi: 10.1186/s12967-019-1836-0

3. Natelson BH. Myalgic Encephalomyelitis/Chronic Fatigue Syndrome and Fibromyalgia: Definitions, Similarities, and Differences. Clin Ther. 2019;41(4):612-8. doi: 10.1016/j.clinthera.2018.12.016

4. Simani L, Ramezani M, Darazam IA, Sagharichi M, Aalipour MA, Ghorbani F, Pakdaman H. Prevalence and correlates of chronic fatigue syndrome and post-traumatic stress disorder after the outbreak of the COVID-19. J Neurovirol. 2021;27(1):154-9.

5. van Campen CM, Rowe PC, Visser FC. Validity of 2-day cardiopulmonary exercise testing in male patients with myalgic encephalomyelitis/Chronic fatigue syndrome. Advances in Physical Education. 2019;10(1);68-80. doi: 10.4236/ape.2020.101007

6. Wyller VBB. Pain is common in chronic fatigue syndrome - current knowledge and future perspectives Scand J Pain. 2019;19(1):5-8. doi: 10.1515/sjpain-2018-2007

7. van Campen CM, Rowe PC, Visser FC. Heart rate thresholds to limit activity in myalgic encephalomyelitis/chronic fatigue syndrome patients (Pacing): comparison of heart rate formulae and measurements of the heart rate at the lactic acidosis threshold during cardiopulmonary exercise testing. Advances in Physical Education. 2020;10(2);138-54. doi: 10.4236/ape.2020.102013

8. Abonie US, Edwards AM, Hettinga FJ. Optimising activity pacing to promote a physically active lifestyle in medical settings: A narrative review informed by clinical and sports pacing research. J Sports Sci. 2020;38(5):590-6. doi: 10.1080/02640414.2020.1721254

9. Chandrasekaran B, Fernandes S, Davis F. Science of sleep and sports performance-a scoping review. Science \& Sports. 2020;35(1);3-11. doi: 10.5935/1984-0063.20200032. 